This journal is the official publication of Bangladesh Society of Physiologists (BSP)

Web URL: www.banglajol.info/index.php/JBSP

Abstracted /indexed in Index Copernicus, Director of Open Access Journal, Index Medicus for South East Asia Region, Google Scholar, 12OR, infobse index, Open $\mathbf{J}$ gate, Cite factor, Scientific indexing services

pISSN-1983-1213; e-ISSN-2219-7508

Article

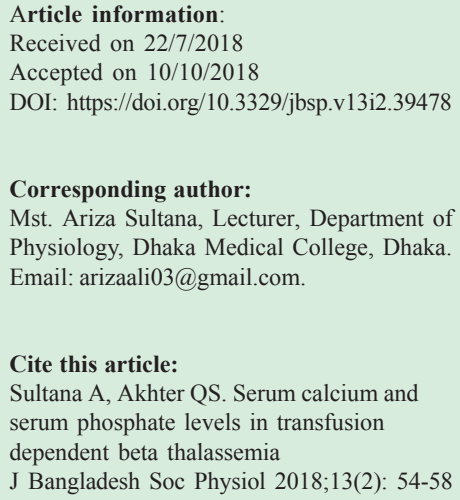

This article is open access licensed under CC BY NC SA which allows readers copy, distribute, display, and perform the work and make derivative works based on it only for noncommercial purposes.

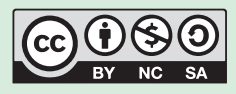

\section{Serum calcium and serum phosphate levels in transfusion dependent beta thalassemia}

\author{
Mst.Ariza Sultana ${ }^{1}$, Qazi Shamima Akhter ${ }^{1}$ \\ 1. Department of Physiology, Dhaka Medical College, Dhaka.
}

\section{Abstract}

Background: Patients with transfusion dependent beta thalassemia with severeanemia require regular blood transfusion to improve quality of life. This can lead to iron overload which might cause various complications including hypocalcaemia.

Objective: To estimate the serum calcium and phosphate levels in transfusion dependent beta thalassemia patients. Methods: This cross-sectional study was conducted in the Department of Physiology, Dhaka Medical College, Dhaka from July 2016 to June 2017. After fulfilling the ethical aspect, a total number of 60 subjects were selected with the age ranging from 5 to 25 years. Among them, 40 transfusion dependent beta thalassemia patients were selected as the study group and 20 age and sex matched apparently healthy individuals were considered as control group for comparison. The study population were selected from Thalassemia foundation hospital, Dhaka. Theserum calcium and phosphate levels were estimated by autoanalyzer.. For statistical analysis, unpaired Student's ' $t$ ' test, Chi-square test were performed as applicable. Results: In this study, serum calcium level were significantly $(\mathrm{p}<0.001)$ lower and serum phosphate level were significantly $(p<0.001)$ higher in transfusion dependent beta thalassemia patients as compared to healthy controls. In addition, $67.5 \%$ thalassemia patients had hypocalcemia (calcium level $<8.5 \mathrm{mg} / \mathrm{dl}$ ) and $85 \%$ of thalassemia patients had hyperphosphatemia(phosphate level $>4.7 \mathrm{mg} / \mathrm{dl}$ ). Conclusions: This study concludes transfusion dependent beta thalassemiapatients have low calcium level and high serum phosphate level which should be monitored to avoid complications related to hypocalcaemia and hyperphosphatemia.

Key words: Iron overload, hypocalcaemia, transfusion dependent beta thalassemia.

J Bangladesh Soc Physiol. 2018, December; 13(2): 54-58 
Introduction

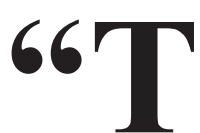

halassemia" name is derived from the Greek words "thalassa" means sea and "haema" means blood. It

is a heterogeneous family of inherited disorders in which there are defective synthesis of $\alpha$ or $\beta$ globin subunits of hemoglobin A and accordingly termed as Alpha $(\alpha)$ or beta $(\beta)$ thalassemia ${ }^{1,2,3}$. Currently, thalassemia has been be classified into Transfusion dependent thalassemias (TDTs) and Nontransfusion dependent thalassemiasdependending on requirement of regular blood transfusion to survive $^{3,4}$.

World Health Organization data shows that about $3 \%$ populations are carriers of beta thalassemia and about $4 \%$ populations are carriers of $\mathrm{Hb}-\mathrm{E}$ in Bangladesh ${ }^{5}$.

The accumulation of excess á-globin chains in erythroid precursors due toimpaired biosynthesis of the â-globin chains in Beta thalassemia major and HbEâ thalassemia leading to red blood cells destruction by oxidative means. All these changes result in ineffective erythropoiesis, hemolysis and anemia and associated with increased mortality fromcongestive cardiac failure or other complications of chronic anemia within few years of life. But this scenario has been changed after treatment started with combination of transfusion and chelation therapy ${ }^{6-10}$.

Despite chelation therapy, repeated blood transfusions may cause iron overload in body which in turn lead to increased load of reactive oxygen species. This increased oxidative stress may damage parathyroid glands in addition to other organs or tissues may cause hypoparathyroidism and hypocalcemia ${ }^{11,12}$.

Calcium and phosphate are major minerals essential for bone rigidity. In addition they exert important role in muscle function, nerve impulse transmission, intracellular signaling, various glandular secretion. Parathyroid hormone is the main regulatory hormone for calcium homeostasis ${ }^{13,14}$. The physiologic balance of phosphate is maintained by coordinated interactions of the small intestine, bone, parathyroid gland and kidney. Functional impairment of any of these organs can lead to abnormal phosphate level ${ }^{15,16}$.

Earlier reports showed lower serum calcium level and higher phosphate level in thalassemia patients than controls 17-18. In addition, correlation of increased calcium level with increased serum ferritin level wasalso reported ${ }^{19}$

It is evident from these previous studies that iron overload due to repeated blood transfusion in thalassemic patients may be attributed to altered calcium and phosphate level in these patients. Though few studies investigated serum calcium and phosphate level in transfusion dependent Thalassemic patients but the volume of data is inadequate to reach a solid conclusion.So, the present study has been designed to reveal the serum calcium and phosphate levels in these patients. The observations may facilitate prevention of transfusion related complication of patients of transfusion dependent beta thalassemia patients.

\section{Method}

This cross sectional study was conducted in the Department of Physiology, Dhaka Medical College, Dhaka from July 2016 to June 2017 after approval from the ethical review committee from this institute. Fourty transfusion dependent beta thalassemia patients aged 5 to 25 years were enrolled from Thalassemia foundation hospital, Dhaka and 20 age and sex matched apparently healthy individuals were selected as control. Informed written consent was taken from the participants after proper briefing about the nature, purpose and benefit of the study. Before taking blood, detailed family and medical history were taken. Anthropometric measurement of the subjects was done and blood pressure was measured. With aseptic precaution, $4 \mathrm{ml}$ of venous blood was collected from ante-cubital vein by a disposable plastic syringe and serum was prepared and sent to lab for estimation serum calcium, phosphate levels by auto analyser. All the parameters were expressed as mean $\pm \mathrm{SD}$. Unpaired Student ' $t$ ' test and Chi- Square test were performed as applicable.P value $<0.05$ was 
accepted as level of significance. Statistical analyses were performed by using a computer based statistical program SPSS (Statistical package for social science) Version 22.0.

\section{Results}

General characteristics of the subjects of both groups are presented in Table I. Mean weight and BMI were significantly lower in thalassemia patients and other variable were not statistically different in both groups. Table II showed significantly lower serum calcium level and higher serum phosphate level in thalassemia patients than controls. This study showed that $67.5 \%$ thalassemia patients had serum calcium level < $8.5 \mathrm{mg} / \mathrm{dl}$ (Figure 1) and $85 \%$ thalassemia patients had phosphate level $>4.7 \mathrm{mg} / \mathrm{dl}$ (Figure 2).

Table I: General characteristics of the subjects in both groups $(\mathrm{N}=60)$

\begin{tabular}{lcc}
\hline & $\begin{array}{c}\text { Control } \\
\left(\mathrm{n}_{1}=20\right)\end{array}$ & $\begin{array}{c}\text { Thalassemia pts } \\
\left(\mathrm{n}_{2}=40\right)\end{array}$ \\
\hline Age (years) & $14.45 \pm 6.52$ & $13.36 \pm 5.02$ \\
Male & $11(55.0 \%)$ & $27(67.5 \%)^{\mathrm{b}}$ \\
Female & $9(45.0 \%)$ & $13(32.5 \%)^{\mathrm{b}}$ \\
Height $(\mathrm{cm})$ & $141.15 \pm 18.37$ & $134.75 \pm 14.43$ \\
Weight $(\mathrm{kg})$ & $40.10 \pm 12.48$ & $29.45 \pm 10.37^{* *}$ \\
BMI $\left(\mathrm{kg} / \mathrm{m}^{2}\right)$ & $19.58 \pm 1.46$ & $15.90 \pm 2.49^{* * *}$ \\
SBP $(\mathrm{mm}$ of Hg) & $102.00 \pm 15.08$ & $97.13 \pm 15.68$ \\
DBP $(\mathrm{mm}$ of Hg) & $58.75 \pm 14.13$ & $58.50 \pm 14.64$ \\
\hline
\end{tabular}

Data were expressed as mean \pm SE. Statistical analysis was done by Unpaired Student's 't' test and Chi square test.

$* *=\mathrm{p}<0.01, * * *=\mathrm{p}<0.001$.

Table II: Serum calcium and serum phosphate levels of the subjects of both groups $(\mathrm{N}=60)$

\begin{tabular}{lcc}
\hline Outcome measures & $\begin{array}{c}\text { Control } \\
(\mathrm{n}=20)\end{array}$ & $\begin{array}{c}\text { Thalassemia } \\
\text { patients }(\mathrm{n}=40)\end{array}$ \\
\hline $\begin{array}{l}\text { Serum Calcium } \\
(\mathrm{mg} / \mathrm{dl})\end{array}$ & $9.04 \pm 0.51$ & $6.90 \pm 2.17^{* * *}$ \\
$\begin{array}{l}\text { Serum Phosphate } \\
(\mathrm{mg} / \mathrm{dl})\end{array}$ & $4.08 \pm 1.40$ & $6.01 \pm 1.38^{* * *}$ \\
\hline
\end{tabular}

Data were expressed as mean $\pm \mathrm{SE}$. Statistical analysis was done by unpaired Student $\mathrm{t}<$ test. $^{* * *}=p<0.001$

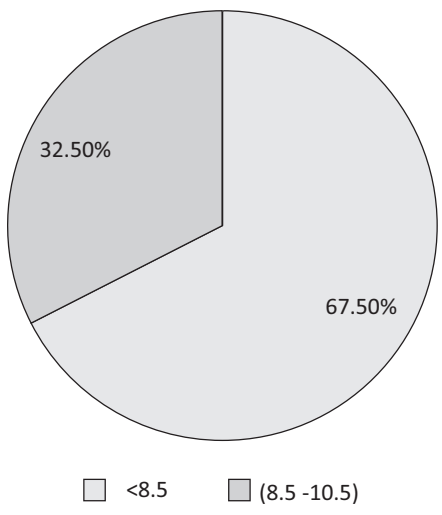

Figure 1: Frequency distribution of serum calcium level in thalassemia patients $(n=40)$

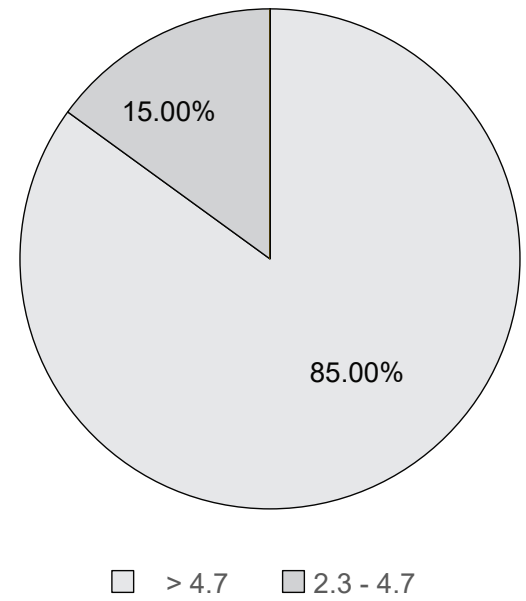

Figure 2: Frequency distribution of serum phosphate level in thalassemia patients $(\mathrm{n}=40)$

\section{Discussion}

The present study was undertaken to assess serum calcium and phosphate levels in transfusion dependent beta thalassemia.In this study, the mean serum calcium level was significantly decreased in transfusion dependent beta thalassemia patients than that of controls. Similar types of observations were reported by some researchers ${ }^{20-22}$. However, some researchers found no change in serum calcium level in beta thalassemia patients. This dissimilarity in findings might be due to variation in nutritional status in study group ${ }^{23}$. 
In the present study, the mean serum phosphate level was increased in transfusion dependent beta thalassemia patients than that of controls and the result was statistically significant. This finding was in agreement with others ${ }^{24-25}$. Again, some investigators found no change in serum phosphate level in beta thalassemia patients. This dissimilarity in findings might be due to variation in nutritional status in study group ${ }^{23}$. Further more, the present results suggested greater percentage of Thalassemia patients were affected with hypocalcemia and hyperphosphatemia indicating their impaired of parathyroid function.

Several studies have suggested that parathyroid gland damage occurs in transfusion dependent beta thalassemia may be due to oxidative stress caused by iron overload. In these patients, excess iron following repeated blood transfusion deposited in various organ including parathyroid gland. These excess iron generate large number of reactive oxygen species (ROS) via Fenton Cs reaction andHaber - Weiss reaction. Reactive oxygen species (ROS) are capable of causing oxidative damage to macromolecules leading to lipid peroxidation, DNA damage and causes damage to parathyroid gland 26,27 .

Again Intracellular iron regulates number of transferrin receptor and serum ferritin levels by interfering the translation of mRNA. When intracellular iron level increase, it stimulates translation of ferritin mRNA and causes degradation of transferrin receptor mRNA. So, there are increase in serum ferritin level and decrease in number of transferrin receptor. As transferrin receptor decrease, excess iron binds with other blood component, leading to formation of plasma non-transferrin bound iron (NTBI). It is potentially toxic and contribute to generation of ROS leading to parathyroid gland damage.As a result decreased serum calcium and increased serum phosphate levels ${ }^{28-30}$.

\section{Conclusions}

After analyzing the results of the study, it may be concluded that lower serum calcium level and higher serum phosphate levels and impaired parathyroid may occurin transfusion dependent beta thalassemia patients. Therefore, estimation of these parameters in transfusion dependent beta thalassemia patients might be useful for early detection of hypocalcaemia and proper management of hypocalcemia to prevent its complication.

\section{Conflict of interest None.}

\section{Acknowledgement}

The authors acknowledge the Thalassemia Foundation Hospital, Dhaka and Department of Biochemistry and Molecular Biology, BSMMU, Dhaka, for their kind co-operation during sample collection and analysis.

\section{References}

1. Goyal M, Abrol P, Lal H. Parathyroid and calcium status in patients with thalassemia. Indian $\mathrm{j}$ Clin Biochem 2010; 25 (4): 385-87.

2. Rachmilewitz EA and Giardina PJ. How I treat thalassemia. Am Soc Hematol. 2011; 118 (13): 3479-488.

3. Muncie HLand Campbell JS. Alpha and beta thalassemia. Am Fam Physician. 2009; 80 (4): 339-44.

4. Viprakasit V and Origa R. Genetic basis, pathophysiology and diagnosis. In:Cappellini MD, Cohen A, Porter J, Taher A, Vipraksit V, eds. Guidelines for the management of transfusion dependent thalassemia (TDT). Nicosa (Cyprus): Thalassemia International Federation. 2014:p. 14-26.

5. Khan WA, Banu B, Amin SK, SelimuzzamanM, Rahman M, Hossain B et al. Prevalence of beta thalassemia trait and $\mathrm{Hb} \mathrm{E}$ tarit in Bangladeshi school children and health burden of thalassemia in our population. Dhaka Shishu Hosp J 2005; 21 (1): 1-7.

6. Scott MD, Van Den Berg JJM, Repka T, RouyerFessard P, Hebbel RP, Beuzard Y et al. Effect of excess á- hemoglobin chains on cellular and membrane oxidation in model â- thalassemic erythrocytes. J Clin Invest. 1993; 91 (4): 1706-12. 
7. Galanello $\mathrm{R}$ and Origa R. Beta thalassemia. Orphanet j Rare Dis? 2010; 5 (11):1-15.

8. Zurlo MG, Stefano PD, Pignatti CB, Palma AD, Piga A, Melevendi $C$ et al. Survival and causes of death in thalassemia major. Inst Res Health. 1989; 2 (8653): 27-30.

9. Chern JPS and Lin KH. Hypoparathyroidism in Transfusion - dependent patients with âthalassemia. J Pediat rhaematol Oncol. 2002; 24 (4): 291-93.

10. Lawson SE, Roberts IAG, Amrolia P, Dokal I, Syzdlo R, Darbyshire PJ. Bone marrow transplantation for â-thalassemia major: the UK experience in two paediatriccentres. British J Haematol. 2003; 120 (2): 289-95.

11. Gardenghi S, Marongiu MF, Ramos P, Guy E, Breda L, Chadburn A at el. Ineffective erythropoiesis in $\alpha$-thalassemia is characterized by increased iron absorption mediated by down-regulation of hepcidin and up-regulation of ferroportin. Am Soc Hematol. 2007; 109 (11): 5027-35.

12. Gupta KK, Mishra A, Tiwari A. Production of reactive oxygen species, its effect, drugs and plant extract used as an antioxidant, chelator on thalassemic patient: a review. Int J Pharm Sci Res. 2011; 2 (9): 2278-85.

13. Jeon US. Kidney and calcium homeostatis.Postech Biotech Centre. 2008; 6 (2): 68-76.

14. Beto JA. The role of calcium in human aging. Clin Nutr Res. 2015; 4 (1): 1-8.

15. Rastegar A. New concepts in pathogenesis of renal hypophosphatemic syndromes. Iran J Kidney Dis. 2009; 3 (1): 1-6.

16. Razzaque MS. The FGF23- klotho axis: endocrine regulation of phosphate homeostasis. Nat Rev Endocrinol. 2009; 5 (11): 611-19.

17. Hagag AA, Ei-Shanshory MR, Ei-Enein AMA. Parathyroid function in children with beta thalassemia and correlation with iron load. Adv Pediatr Res. 2015; 2 (3): 1- 6.

18. Mahdi NE, Garadah TS, Hassan Z, Jaradat AA, Nagalla DS. The prevalence of adrenal, parathyroid and cardiac dysfunction in patients with beta thalassemia major. Int J Clin Med. 2013; 4 (7): 325-30.

19. Adil A, Sobani ZA, Jabbar A, Adil SN, Awan S. Endocrine complications in patients of beta thalassemia major in a tertiary care hospital in Pakistan. J Pak Med Assoc. 2012; 62 (3): 307-10.

20. Hamidieh AA, Moradbeag B, Pasha F, Jalili M, Hadjibabaie M, Keshavarznia M. High prevalence of hypoparathyroidism in patients with beta thalassemia major. Int J Hematol Oncol Stem Cell Res. 2009; 3 (3): 17-20.

21. Habeb AM, Al-Hawasawi ZM, Morsy MM, Al-Harbi AM, Osilan AS, Al-Magamsi MS et al. Endocrinopathies in beta thalassemia major. Saudi Med J. 2013; 34 (1): 67- 73.

22. Patne A, Hisalkar PJ, Gaikwad SB, Karnik A. Evaluation of HPT markers in â thalassemia major patients. Indian J Appl Res. 2014; 4 (1): 389-390.

23. Mahachoklertwattana $p$, Sirikulchayanonta V, Chuansumrit A, Karnsombat P, Choubtum L, SriphrapradangA et al. Bone histomorphometry in children and adolescents with beta thalassemia disease: iron associated focal osteomalacia. J Clin Endocrinol Metab. 2003; 88(8): 3966 - 72.

24. Aleem A, Al-Momen AK, Al-Harakati MS, Hassan A, Al-Fawaz I. Hypocalcemia due to hypoparathyroidism in â thalassemia major patients. Ann Saudi Med. 2000; 20 (5-6): 364-66.

25. Modi AS, Poornima RT, Murthy JDS. Serum calcium and phosphate levels in patients with â thalassemia major. Int J Pharm Bio Sci. 2012; 2 (4): 156-60.

26. Hershko C. Pathogenesis and management of iron toxicity in thalassemia. Ann N Y Acad Sci. 2010; 1202 (1): 1-9.

27. Patne A, Hisalkar PJ, Gaikwad SB, Karnik A. Evaluation of HPT markers in â thalassemia major patients. Indian J Appl Res. 2014; 4 (1): 389-390.

28. Theil EC. Regulation of ferritin and transferrin receptor mRNAs. J Biol Chem. 1990; 265 (9): 4771-74.

29. Khumalo H, Gomo ZAR, Moyo. VM, Gordeuk VR, Saungweme T, Rouault TA, Gangaidzo IT. Serum transferrin receptors are decreased in the presence of iron overload. Clin Chem. 1998; 44 (1): 40-4.

30. Brissot P, Ropert M, Lan CL, Loreal O. Nontransferrin bound iron: a key role in iron overload and iron toxicity. Biochim Biophys Acta. 2011; 1820 (3): 403-10. 